\title{
Genetic variability and Association studies for Gall Midge Incidence, Yield and Its Traits in Rice (Oryza sativa L.) Genotypes
}

\author{
S. Sreedhar* \\ Rice Breeding Scheme, Agricultural Research Station, Kunaram - 505 174, Peddapalli \\ District, Professor Jayashankar Telangana State Agricultural University, \\ Telangana State, India \\ *Corresponding author
}

\begin{tabular}{|l|}
\hline Ke y w o r d s \\
Rice, PCV, GCV, \\
$\begin{array}{l}\text { Heritability, Genetic } \\
\text { advance, Correlation } \\
\text { coefficient, Yield }\end{array}$ \\
\hline Article Info \\
\hline $\begin{array}{l}\text { Accepted: } \\
\text { 18 September } 2018 \\
\text { Available Online: } \\
10 \text { October } 2018\end{array}$ \\
\hline
\end{tabular}

\section{Introduction}

Rice is one of the most important food crops and a primary source of food for more than half of the world's population. Though enormous progress has been made in recent past in improving yield levels with the use of high yielding varieties, still there is a pressing need for improving productivity in rice varieties by exploiting available variability in
Rice is the most important staple food crop in the world particularly in South East Asia and gets infested with gall midge which is an important pest especially during rainy season with delayed sowings resulting in huge losses to the farmers in Northern Telangana Zone, India. Forty five genotypes were studied for the estimation of genetic variability at Agricultural Research Station, Kunaram, Telangana. The GCV and PCV were high for number of grains per panicle, gall midge incidence and grain yield, whereas, low for days to maturity, plant height and panicle length. Additive gene action was predominant for number of grains per panicle, 1000-grain weight, gall midge incidence and grain yield as they registered high heritability coupled with high genetic advance values. Investigation on association studies expressed that genotypic correlation coefficients were higher than the corresponding phenotypic correlation coefficients except panicle length demonstrating that observed relationships between yield and yield components due to genetic causes. It is noticed that plant height, panicle length, number of productive tillers per $\mathrm{m}^{2}$ and 1000 grain weight exhibited significant positive association with grain yield, whereas, gall midge incidence expressed significant negative association with grain yield at both genotypic and phenotypic levels indicating the genotypes with more plant height, longer panicles, good number of productive tillers and long bold grains with relatively very less number of silver shoots contribute for high grain yield and gall midge resistance. 
magnitude of variability in the germplasm and its critical analysis is a pre-requisite for the refinement of rice varieties with more yield along with gall midge resistance for adopting of appropriate selection techniques. The available variability in a population can be partitioned into heritable and non-heritable parts with the aid of genetic parameters such as coefficient of variation, heritability and genetic advance (Miller et al., 1958).

Heritability is the heritable portion of a character from parents their offspring (Falconer, 1981). The estimates of heritability help the plant breeders to provide information on the proportion of variation that is transmissible to the progenies in the subsequent generations and selection of elite genotypes from genetic populations. Moreover, heritability estimates in conjunction with genetic advance are normally more helpful in predicting the gain under selection. Rice grain yield being a complex trait, depends upon the various yield contributing traits like test weight, number of grains per panicle, panicle length, effective bearing tiller number etc. Character association derived by correlation coefficient which is one of the important biometrical tools for formulating a selection index as it reveals the strength of relationship among the group of traits. The type and extent of correlation between the yield and other characters helps in estimating the relative effect of the individual traits on yield improvement thereby enable the breeders to identify desirable traits that play a key role in yield improvement. Knowledge about the relationship between a trait with yield and other yield components would be helpful in selecting proper rice genotypes as parents in breeding programmes.

Keeping in view of the importance, present study was undertaken to assess the variability, heritability and genetic advance and to estimate the association between yield, its components and gall midge incidence for further improvement to derive high yielding rice genotypes with gall midge resistance and desirable agronomic traits to attain selfsufficiency and meet the future demand resulting from population growth.

\section{Materials and Methods}

The experiment was conducted at Agricultural Research Station, Kunaram, Telangana, India. The experimental material consisted of 45 rice genotypes and their seed was raised on nursery beds and 25 days old seedlings of each entry was transplanted under irrigated system with two replications in a RBD design during kharif, 2017. All the recommended package of practices and need based plant protection measures were followed to ensure healthy crop growth. The data was recorded at maturity on 5 random plants for plant height $(\mathrm{cm})$, panicle length $(\mathrm{cm})$, number of productive tillers per $\mathrm{m}^{2}$ and number of grains per panicle. However, days to $50 \%$ flowering, days to maturity and grain yield $(\mathrm{kg})$ were recorded on whole plot basis, whereas, random sample was taken to estimate 1000 grain weight $(\mathrm{g})$ for each entry in each replication. Number of productive tillers per plant values were converted into the number of productive tillers per $\mathrm{m}^{2}$ and grain yield values recorded from the net plot (kg per plot) were converted in to hectare ( $\mathrm{kg}$ per ha). The incidence of gall midge was recorded as percent tillers affected with silver shoots (SES, IRRI, 2002) on 10 random plants and averaged.

The mean data after computing for each trait was subjected to analysis of variance (Panse and Sukhatme, 1985), genotypic coefficient of variation (GCV), phenotypic coefficients of variation (PCV) following the formula suggested by (Falconer, 1981), heritability $\left(\mathrm{h}^{2}\right)$ in the broad sense as suggested by (Allard, 1960), genetic advance (Burton, 1952) and 
correlations (Robinson et al., 1951) following standard procedures.

\section{Results and Discussion}

In the present investigation, analysis of variance (Table 1) revealed highly significant differences among the genotypes for all the traits studied indicating the presence of considerable amount of variability among the genotypes. The perusal of the variability estimates (Table 1) for yield and its contributing traits exhibited that genotypic coefficient of variation (GCV) and phenotypic coefficient of variation (PCV) were high for number of grains per panicle, gall midge incidence and grain yield suggesting the presence of high degree of variation for these traits among the genotypes which could be improved through selection in desirable direction. These results are in agreement with the findings obtained by Mohan et al., (2015), Sameera et al., (2015), Srinivas et al., (2016) and Ajmera et al., (2017) for number of grains per panicle; Ahmed et al., (2010), Sameera et al., (2015) and Ajmera et al., (2017) for 1000grain weight; Ajmera et al., (2017) for productive tillers per plant; Mohan et al., (2015) and Thippaswamy et al., (2016) for gall midge incidence; Allam et al., (2015), Bhati et al., (2015) and Ajmera et al., (2017) for grain yield. In contrary to this, Akinwale et al., (2011) and Ramanjaneyulu et al., (2014) reported moderate GCV and high PCV values for grain yield. Highest GCV and PCV values were observed for gall midge incidence among all the traits which is supported by Mohan et al., (2015) and Thippaswamy et al., (2016).

Low levels of PCV and GCV were observed for panicle length, plant height and days to maturity suggesting need for creation of variability with hybridization followed by selection. Similar reports were concluded by Akinwale et al., (2011) and Sangram Kumar et al., (2011) for panicle length and plant height. In contrary to this, Dhanwani et al., (2013) and Ajmera et al., (2017) reported moderate estimates for panicle length, and also Dhanwani et al., (2013) showed high GCV and PCV for plant height.

High estimates of PCV were observed than GCV for all the traits studied which may be due to the high degree of interaction of genotypes with environments. Similar findings were earlier reported by Vanisree et al., (2013), Ketan and Sarkar (2014), Mohan et al., (2015), Srinivas et al., (2016) and Ajmera et al., (2017).

Narrow differences between the corresponding estimates of PCV and GCV were observed for days to maturity, plant height, panicle length and 1000-grain weight indicated the presence of high genetic variability and less interference of environment on expression of these traits which may facilitate selection for further crossing programme. These results were supported by Mohan et al., (2015) and Ajmera et al., (2017) for plant height, panicle length and 1000 grain weight. However, estimates of PCV were considerably higher than GCV for days to $50 \%$ flowering, number of productive tillers per $\mathrm{m}^{2}$, number of grains per panicle, gall midge incidence and grain yield indicating the sensitive nature of these traits to environmental fluctuations and predominance of non-additive gene effects. Similar findings are in accordance with the earlier reports of Mohan et al., (2015) and Thippaswamy et al., (2016) for effective bearing tillers, number grains per panicle, gall midge incidence and grain yield.

All the traits except days to flowering and number of productive tillers per $\mathrm{m}^{2}$ recorded high estimates of the heritability (Table 1) in the broad sense indicated that these traits could be improved through selection based on their phenotype. Since, days to $50 \%$ flowering and number of productive tillers per $\mathrm{m}^{2}$ had 
relatively low estimates, improvement through selection could be low due to masking effect of environment on the expression of these traits. Similarly, moderate heritable values were reported by Sangram Kumar et al., (2011), Thomas and Gabriel (2012) for test weight, Ramanjaneyulu et al., (2014) for days to flowering and panicle length. High heritability alone does not guarantee large gain from selection unless sufficient genetic advance attributed to additive gene action is present. In the present investigation, high heritability coupled with high genetic advance values were observed for number of grains per panicle, 1000-grain weight, gall midge incidence and grain yield which indicated that these traits were predominantly governed by the additive genes which can be scored by their phenotypic performance. Similar results were reported by Karande et al., (2015) and Ajmera et al., (2017) for number of grains per panicle; Toshimenla and Changkija (2013), Chandramohan et al., (2016), Islam et al., (2016), Srinivas et al., (2016) and Ajmera et al., (2017) for 1000-grain weight; Mohan et al., (2015) for gall midge incidence; Rahman et al., (2014), Karande et al., (2015) and Ajmera et al., (2017) for grain yield. Similarly, high heritability coupled with moderate genetic advance estimates were recorded for days to maturity, plant height and panicle length. Ketan and Sarkar (2014) and Chandramohan et al., (2016) supported the present findings for plant height and panicle length suggesting the role of both additive and non-additive gene effects in their inheritance, therefore, adoption of breeding procedures which could exploit both the gene actions would be a prospective approach. In contrary to this, Sameera et al., (2015) reported high heritability coupled with high genetic advance for the traits plant height and panicle length.

Genotypic and phenotypic correlations (Table 2) were in perfect agreement with each other and relatively higher magnitude of genotypic correlations for all the traits except panicle length indicated the masking effect of the environment. Similar results were reported by Ravindra Babu et al., (2012), Mohan et al., (2015), Ratna et al., (2015) and Kalyan et al., (2017).

The grain yield showed significantly positive correlation with plant height, panicle length, number of productive tillers per $\mathrm{m}^{2}$ and 1000grain weight at both genotypic and phenotypic levels. These results clearly indicated that genotypes with more plant height, longer panicles, good number of productive tillers and bold grains contribute for more grain yield. The results are in agreement with Akinwale et al., (2011), Ravindra babu et al., (2012) and Ratna et al., (2015) for productive tillers per plant and, Ramanjaneyulu et al., (2014), Mohan et al., (2015) and Islam et al., (2016) for test weight. While, days to $50 \%$ flowering showed significant positive correlation with grain yield at genotypic level. This result suggests longer duration genotypes contribute for more yield. However, negative relationship between days to $50 \%$ flowering and grain yield was reported by Babu et al., (2006) and Chandan kumar and Nilanjaya, (2014). The gall midge incidence expressed significant negative association with grain yield at both phenotypic and genotypic levels indicated the genotypes with less silver shoots were high yielders.

Inter correlation studies may facilitate breeder to decide upon the intensity and direction of selection pressure to be given on related traits for simultaneous improvement of these traits. Gall midge incidence exhibited significant negative correlation with plant height, number of productive tillers per $\mathrm{m}^{2}, 1000$ grain weight and grain yield at both genotypic and phenotypic levels indicating high yielding tall stature with long bold grains and good number of productive tillers genotypes were relatively tolerant to gall midge incidence. 
Table.1 Mean squares corresponding to various sources of variation and genetic parameters for gall midge incidence, grain yield and its components in rice

\begin{tabular}{|c|c|c|c|c|c|c|c|c|c|c|}
\hline Source of variation & $\begin{array}{l}\text { Degrees } \\
\text { of freedom }\end{array}$ & $\begin{array}{l}\text { Days to } 50 \% \\
\text { flowering }\end{array}$ & $\begin{array}{l}\text { Days to } \\
\text { maturity }\end{array}$ & $\begin{array}{l}\text { Plant height } \\
\quad(\mathrm{cm})\end{array}$ & $\begin{array}{l}\text { Number of } \\
\text { productive } \\
\text { tillers per } \mathbf{m}^{2}\end{array}$ & $\begin{array}{c}\text { Panicle } \\
\text { length }(\mathrm{cm})\end{array}$ & $\begin{array}{l}\text { Number } \\
\text { of grains per } \\
\text { panicle }\end{array}$ & $\begin{array}{c}\text { 1000- grain } \\
\text { weight (g) }\end{array}$ & $\begin{array}{c}\text { Gall midge } \\
\text { incidence }(\%)\end{array}$ & $\begin{array}{c}\text { Grain yield (kg/ } \\
\text { ha) }\end{array}$ \\
\hline Treatments & 44 & $202.80^{* *}$ & $107.99 * *$ & $119.38^{* *}$ & $2814.43 * *$ & $6.93 * *$ & $2437.29 * *$ & $14.59^{* *}$ & $758.27 * *$ & $4530526.67 * *$ \\
\hline Error & 44 & 87.06 & 2.74 & 4.95 & 1053.75 & 0.80 & 388.68 & 1.16 & 47.35 & 527455.16 \\
\hline MMM Mean & & 96.59 & 128.70 & 98.47 & 160.67 & 98.47 & 155.16 & 23.48 & 4570.80 & 70.93 \\
\hline R Range & & $48.00-113.50$ & $112.50-142.00$ & 71.95-113.45 & $100.00-265.00$ & $20.70-29.30$ & $101.80-276.50$ & $13.05-27.45$ & $4.40-89.95$ & $2087.00-8213.00$ \\
\hline GCV & & 7.88 & 5.64 & 7.68 & 18.47 & 6.80 & 20.63 & 11.04 & 30.95 & 26.58 \\
\hline PCV PCV & & 12.46 & 5.78 & 8.01 & 27.37 & 7.64 & 24.23 & 11.95 & 34.79 & 28.29 \\
\hline$h^{2}$ (broad sense) & & 0.39 & 0.95 & 0.92 & 0.46 & 0.79 & 0.73 & 0.85 & 0.79 & 0.88 \\
\hline
\end{tabular}

$*$,** significant at 5 and 1 per cent level

GCV: Genotypic Coefficient of Variation; PCV: Phenotypic Coefficient of Variation

Table.2 Phenotypic (P) and genotypic (G) correlation coefficients among gall midge incidence, grain yield and its components in rice genotypes

\begin{tabular}{|c|c|c|c|c|c|c|c|c|c|c|}
\hline Character & & $\begin{array}{l}\text { Days to } 50 \% \\
\text { flowering }\end{array}$ & $\begin{array}{l}\text { Days to } \\
\text { maturity }\end{array}$ & $\begin{array}{c}\text { Plant } \\
\text { height }(\mathrm{cm})\end{array}$ & $\begin{array}{c}\text { Panicle } \\
\text { length }(\mathrm{cm})\end{array}$ & $\begin{array}{c}\text { Number of productive } \\
\text { tillers per } \mathrm{m}^{2}\end{array}$ & $\begin{array}{c}\text { Number of grains } \\
\text { per panicle }\end{array}$ & $\begin{array}{l}1000 \text { grain } \\
\text { weight }(\mathrm{g})\end{array}$ & Galls (\%) & $\begin{array}{c}\text { Grain yield } \\
\text { (kg/ ha) }\end{array}$ \\
\hline \multirow[t]{2}{*}{ Days to $50 \%$ flowering } & $\mathrm{P}$ & 1.0000 & $0.5773 * *$ & 0.0196 & 0.1318 & 0.0241 & 0.0131 & $-0.2282 *$ & -0.0045 & 0.1306 \\
\hline & G & 1.0000 & $0.9562 * *$ & -0.0836 & 0.1398 & 0.0949 & 0.0009 & $-0.4115^{* *}$ & -0.0199 & $0.2200^{*}$ \\
\hline \multirow[t]{2}{*}{ Days to maturity } & $\mathrm{P}$ & & 1.0000 & 0.0113 & $0.3022 * *$ & -0.0302 & -0.0210 & -0.1682 & 0.0345 & 0.0537 \\
\hline & G & & 1.0000 & -0.0022 & $0.3291 * *$ & -0.0556 & -0.0211 & -0.1740 & 0.0460 & 0.0186 \\
\hline \multirow[t]{2}{*}{ Plant height $(\mathrm{cm})$} & $\mathrm{P}$ & & & 1.0000 & 0.1097 & 0.0353 & 0.2050 & 0.1748 & $-0.4196^{* *}$ & $0.3156^{* * *}$ \\
\hline & G & & & 1.0000 & 0.1493 & -0.0075 & $0.2549 *$ & 0.2059 & $-0.4357 * *$ & $0.3628 * *$ \\
\hline \multirow[t]{2}{*}{ Panicle length (cm) } & $\mathrm{P}$ & & & & 1.0000 & -0.0716 & -0.1203 & 0.1513 & 0.1076 & $0.2908 * *$ \\
\hline & G & & & & 1.0000 & -0.1913 & $-0.2453^{*}$ & 0.2057 & 0.1194 & $0.2702 * *$ \\
\hline \multirow{2}{*}{$\begin{array}{c}\begin{array}{c}\text { Number of productive } \\
\text { tillers per } \mathrm{m}^{2}\end{array} \\
\end{array}$} & $\mathrm{P}$ & & & & & 1.0000 & -0.0443 & -0.0122 & $-0.4982 * *$ & $0.2710^{* *}$ \\
\hline & G & & & & & 1.0000 & -0.0998 & 0.0056 & $-0.6294 * *$ & $0.3047 * *$ \\
\hline \multirow{2}{*}{$\begin{array}{c}\text { Number of grains per } \\
\text { panicle }\end{array}$} & $\mathrm{P}$ & & & & & & 1.0000 & $-0.4393 * *$ & -0.0330 & -0.0070 \\
\hline & G & & & & & & 1.0000 & $-0.4850 * *$ & -0.0487 & -0.1058 \\
\hline \multirow{2}{*}{1000 grain weight $(\mathrm{g})$} & $\mathrm{P}$ & & & & & & & 1.0000 & $-0.3130^{* *}$ & $0.2864^{* *}$ \\
\hline & $\mathrm{G}$ & & & & & & & 1.0000 & $-0.3508^{* *}$ & $0.3738^{* *}$ \\
\hline \multirow[t]{2}{*}{ Galls (\%) } & $\mathrm{P}$ & & & & & & & & 1.0000 & $-0.5904 * *$ \\
\hline & G & & & & & & & & 1.0000 & $-0.6595^{* *}$ \\
\hline
\end{tabular}

P: Phenotypic correlation coefficients, G: Genotypic correlation coefficients

$*$, ** significant at 5 and 1 per cent level

Gen: $\mathrm{R}^{2}=-0.6363$; Residual effect $=1.2792$

Phe: $R^{2}=0.4965$; Residual effect $=0.7096$ 
Hence, selection of genotypes in this direction might help for gall midge resistance. These results are contrary to Ogunbayo et al., (2010), Mohan et al., (2015) and Tippaswamy et al., (2016) as test weight and effective bearing tillers were positively associated with gall midge incidence in their findings.

Days to $50 \%$ flowering exhibited significant positive association with days to maturity at both genotypic and phenotypic levels, whereas, it manifested significant negative correlation with 1000-grain weight at both genotypic and phenotypic levels indicating the long bold grain varieties were with early duration. Days to maturity exhibited significant and positive correlation with panicle length and days to flowering at both genotypic and phenotypic levels. Plant height exhibited significant positive correlation with grain yield and negative correlation with gall midge incidence at both phenotypic and genotypic levels, whereas, it recorded significant positive correlation with number of grains per panicle at genotypic level. Chandan Kumar and Nilanjaya, (2014) obtained negative association for the plant height with tillers per plant and grains per panicle. The trait, number of productive tillers per $\mathrm{m}^{2}$ exhibited significant positive and negative correlations with grain yield and silver shoots, respectively. Panicle length had positive correlation with days to maturity and days to $50 \%$ flowering, where as it exhibited negative correlation with number of grains per panicle at genotypic level. Ravindra Babu et al., (2012), Mohan et al., (2015) reported positive correlation between panicle length and days to $50 \%$ flowering.

The trait, number of grains per panicle showed negative correlation with grain yield and significant negative correlation with 1000-grain weight indicating the practice of selecting long bold grain genotypes would enhance the yield levels. Akinwale et al.,
(2011), Ruth Elizabeth Ekka et al., (2011), Ravindra babu et al., (2012), Gopikannan and Ganesh (2013) and Ratna et al., (2015) reported the positive association of grain yield with filled grains per panicle which was contradictory with this study. Moreover, positive and significant association of grains per panicle with 1000 grain weight was earlier reported by Deepa sankar et al., (2006) and Chandan kumar and Nilanjaya, (2014).

Test weight exhibited significantly negative correlation with gall midge incidence, days to $50 \%$ flowering and number of grains per panicle. Mohan et al., (2015) also obtained similar results for number of grains per panicle. These above correlations also indicated that by selecting any one the above traits might be useful to improve the grain yield along with gall midge resistance. Days to maturity and panicle length showed negative associations with some of the traits, but these two traits had significant positive association between them. Pleiotrophy and /linkage may also be the genetic reasons for this type of negative association.

On the basis of results as summarized above, it is concluded that number of grains per panicle, 1000-grain weight, gall midge incidence and grain yield showed high heritability coupled with high genetic advance values indicating these traits were predominantly governed by the additive genes which could be improved through simple selection procedures. Grain yield had positively correlated with plant height, panicle length, number of productive tillers per $\mathrm{m}^{2}$ and 1000-grain weight, and negatively correlated with gall midge incidence at both genotypic and phenotypic levels suggesting genotypes with more plant height, longer panicles, good number of productive tillers and long bold grains with relatively very less silver shoots contribute for more grain yield. Thus, these plant traits deserve greater 
attention in further breeding programmes for developing high yielding gall midge resistant rice varieties.

\section{References}

Ahmed, H., Razvi, S.M., Ashraf Bhat, M., Najeeb, S., Wani, N., Habib, M., Mir, M.R and Gupta, B.B. 2010. Genetic variability and genetic divergence of important rice (Oryza sativa L.) varieties. Int. J. Curr. Res. 4: 33-37.

Ajmera, S., Sudheer Kumar, S and Ravindra babu, B. 2017. Evaluation of Genetic Variability, Heritability and Genetic Advance for Yield and Yield Components in Rice Genotypes. Int.J.Pure.App.Biosci. 5(4):909-915.

Akinwale, M.G., Gregorio, G., Nwilenel, F., Akinyele, B.O., Ogunbayo, S.A and Odiyi, A.C. 2011. Heritability and correlation coefficient analysis for yield and its components in rice (Oryza sativa L.). African. J. Plant. Sci. 5: 207-212.

Allam, C.R., Jaiswal, H.K., Qamar, A., Venkateshwarlu, C and Reddy, Y.S. 2015. Variability, heritability and genetic advance studies in some indigenous genotypes of basmati rice (Oryza sativa L.). Electron. J. Plant. Breed. 6(2):506-511.

Allard, R.W., 1960. Principles of plant breeding. Publishers by John Wiley and Sons Inc. New York USA, 485.

Babu, S and Yogammenakshi P. 2006. Path analysis in hybrid rice (Oryza sativa L.) over salt environments. Oryza. 43(3): 238-240.

Bhati, P. K., Singh, S.K., Dhurai, S.Y and Amita Sharma. 2015. Genetic divergence for quantitative traits in rice germplasm. Electron. J.Plant. Breed. 6(2):528-534.

Burton, G.W., 1952. Quantitative inheritance in grasses. Proceeding of sixth International Congress, 277-283.
Chandan kumar and Nilanjaya. 2014. Correlation and Path Coefficient Analysis of Yield Components in Aerobic Rice (Oryza sativa L.). The Bioscan. 9(2): 907-913.

Chandramohan, Y., Srinivas, B., Thippaswamy, S and Padmaja, D. 2016. Diversity and variability analysis for yield parameters in rice (Oryza sativa L.). Indian. J. Agri. Res. 50 (6): 609613.

Deepa Sankar, P., Sheeba, A and Anbumalarmathi, J. 2006. Variability and character association studies in rice (Oryza sativa L.). Agri. Sci. Digest. 26(3):182-184.

Dhanwani, R.K., Sarawgi, A.K., Solanki, A and Tiwari, J.K. 2013. Genetic variability analysis for various yield attributing and quality traits in rice (Oryza sativa L.). The bioscan. 8(4): 1403-1407.

Falconer, D.S., 1981. Introduction to quantitative genetics. Oliver and Boyd, London, 340.

Gopikannan, M and S.K. Ganesh. 2013. InterRelationship and Path Analysis in Rice (Oryza sativa L.) under Sodicity. Indian. J. Sci. Tech. 6(9): 5223-5227.

Islam, M.Z., Khalequzzaman, M., Bashar, M.K., Ivy, N.A., Haque, M.M and Mian, M. A. K. 2016.Variability assessment of aromatic and fine rice germplasm in Bangladesh based on quantitative traits. The Scientific World J. Article ID 2796720, 14 pages.

Kalyan, B., Radhakrishna, K.V and Subbarao, L.V. 2017. Path coefficient Analysis for Yield and Yield contributing traits in Rice (Oryza sativa L.) Genotypes. Int.J.Curr.Microbiol.App.Sci. $\quad$ 6(7): 2680-2687.

Karande, S.S., Thaware, B.L., Bhave, S.G and Burondkar, M.M. 2015. Estimate of genetic variability and heritability in some exotic germplasm lines in kharif 
rice (Oryza sativa L.). Int. J. Appl. Biol. Pharma. Tech. 6(4): 128-130.

Ketan, R. and Sarkar, G. 2014. Studies on variability, heritability, genetic advance and path analysis in some indigenous Aman rice (Oryza sativa L.). J. Crop. Weed. 10(2): 308-315.

Miller, P.A., Williams, C., Robinson, H.F and Comstock, R.E. 1958. Estimates of genotypic and environmental variance and covariance and implication in section. Agro. J. (50): 126-131.

Mohan, Y.C., Thippeswamy, S., Bhoomeshwar, K., Madhavilatha, B and Jameema Samreen. 2015. Diversity analysis for yield and gall midge resistance in rice (Oryza sativa L.) in northern telangana zone, India. SABRAO J. Breed. and Gen. 47(2): 160171.

Ogunbayo, S.S., Dakouo, M., Sanou, D., Dembele, Y., N' dri B, Drame, K.N., Sanni, K.A, Toulou, B and Glele, R.K (2010). Evaluation of intra and interspecific rice varieties adapted to valley bottom conditions in Burkina Faso. Africa Rice Centre (WARDA), Cotonou, Benin.Afr.J.Plant Sci. 4(8):308-318.

Panse, V.G. and Sukhatme, P.V. 1985. Statistical methods for agricultural workers, $2^{\text {nd }}$ edition ICAR, New Delhi, pp: 361

Rahman, M.A., Hossain, M.S., Chowdary, I.F., Matin, M.A and Mehraj, H. 2014. Variability study of advanced fine rice with correlation, path co-efficient analysis of yield contributing characters. Int.J. Appl.Sci. Biotech. 2(3):364-370.

Ramanjaneyulu, A.V., Gouri Shankar, V., Neelima, T.L and Shashibhushan, D. 2014. Genetic analysis of rice (Oryza sativa L.) genotypes under aerobic conditions on alfisols. SABRAO J. Breed. and Gen. 46 (1): 99-111.
Ratna, M., Begum, S., Husna, A., Dey, S.R and Hossain M.S. 2015. Correlation and path coefficients analyses in basmati rice. Bangladesh J. Agril. Res. 40(1): 153-161.

Ravindra Babu, V., Shreya, K., Kuldeep Singh Dangi., Usharani, G and Nagesh, P. 2012. Genetic variability studies of qualitative and quantitative traits in popular rice (Oryza sativa L.) hybrids of India. Int. J. Scientific and Res. Publi. 2(6): 1-5.

Robinson, H.F., Comstock, R.E and Harvey, P.H.1951. Genotypic and phenotypic correlations in corn and their implications in selection. Agron. $J$. 43:262-267.

Ruth Elizabeth Ekka., Sarawgi, A.K. and Raja R.Kanwar 2011. Correlation and Path analysis in Traditional Rice Accessions of Chhattisgarh. J. Rice. Res. 4(1\&2): 11-18.

Sameera, S.K., Prasannarajesh, A., Jayalakshmi, V., Nirmala, P.J and Srinivas, T. 2015. Genetic variability studies for yield and yield components in rice (Oryza sativa L.). Elec.J.Plant Breed. 6 (1):269-273.

Sangram kumar, S., Mohan, C.S and Lal, G.M. 2011. Assessment of genetic variability for yield and its component characters in rice (Oryza sativa L.). Res. in Plant. Biolo. 1(4): 73-76.

Srinivas, B., Chandramohan, Y., Thippaswamy, S and Padmaja, D. 2016. Genetic Variability and Divergence Studies for Gall midge Resistance and Yield Components in rice (Oryza sativa L.). Int. J. Bio-resource. Stress Management. 7(1): 001-007.

Thippaswamy, S., Chandramohan, Y., Srinivas, B and Padmaja, D. 2016. Selection of diverse parental lines for heterotic hybrid development in rice (Oryza sativa L.). SABRAO J. Breed. Gen. 48(3): 285-294. 
Thomas, N and Gabriel, M.L. 2012. Genetic divergence in rice genotypes under irrigated conditions. Ann. Plant. Soil. Res.14 (2): 109-112.

Toshimenla and Changkija, S. 2013. Genetic variability in yields and its component characters in upland rice of Nagaland. Indian J. Hill Farming. 26(2): 84-87.

Vanisree, S., Swapna, K., Damodar Raju, Ch., Surender Raju, Ch and Sreedhar, M. 2013. Genetic variability and selection criteria in rice. J. Biolo. Scientific Opinion. 1(4): 342-346.

\section{How to cite this article:}

Sreedhar, S. 2018. Genetic variability and Association studies for Gall Midge Incidence, Yield and Its Traits in Rice (Oryza sativa L.) Genotypes. Int.J.Curr.Microbiol.App.Sci. 7(10): 21952203. doi: https://doi.org/10.20546/ijcmas.2018.710.252 